\title{
Fiber Waste From Cotton Process Technological Processes
}

\author{
Abbazov Ilkhom, Xodjiev Muksin, Makhkamov Iqbol
}

\begin{abstract}
This article shows the changes in fiber waste from cotton processing and how it is gradual. The dust emitted in the dry-cleaning shop is only 5-7 mg/m $\mathrm{m}^{3}$ of dust, less than the air in the building where the drying machines are located. This is due to the fact that high moisture is absorbed into the dryers, which prevents the separation of fine dust from the mass. The large dispersed dust, even at high humidity, was separated and was unable to disperse in the building. In the drying units, dust that comes with an atmospheric drying agent causes trouble. This dust, even with a rough dispersion, sits in the dryer along with the gas flow to the roof of the building and the ground near the drying shop. The amount of dust released is $500-600 \mathrm{~kg} / \mathrm{day}$. In the compartment, the dust emits from the air pneumatic system, which is an indispensable dust in the air drying shop, as well as the dust generated by cleaning machines. This is a powdery fiber, which contains less mineral fractions. The small fractions are composed of mostly dirty particles. Powdered air is also isolated from aspirate systems of gin suppliers, which absorb absorbed air or polluted air from pollutants. Such suction system can be included in the aspiration of the cotton distribution screw. It is established that only one cotton gin industry produces 150-350 tons of fiber per year, industry-wide waste is 5-6 tons, and 70-90\% of organic waste is non-toxic. This will serve as a feedstock for the use of animal feed in the agricultural sector. Researches have been carried out to identify the amount of emissions from the ginneries at the Karasu, Mustaqillik and Ginnery factories in the Tashkent region and the Metan cotton gin enterprises in Samarkand region.

Index Terms: powder holders, dust, mineral waste, organic waste, technological process, cotton, cleaning plant.
\end{abstract}

\section{INTRODUCTION}

At all stages of the initial cotton processing, a large amount of dust is emitted, which can pollute the production facilities and the ambient air, which can worsen the working conditions of workers and employees and cause them to develop occupational diseases, including silicosis. The issue of dehydration of ginneries is of paramount importance due to increased pollution of cotton harvested cars. With the increasingly widespread introduction of machine-picking, the cotton ginning industry needs immediate action not only to receive, store and process the cotton, but also to improve the

Revised Manuscript Received on February 05, 2020.

* Correspondence Author

Khodjiev Muksin*, Professor of Guliston State University, Gulistan, Uzbekistan.

Abbazov Ilkhom, PhD of Jizzakh Polytechnical Institute, Jizzakh, Uzbekistan.

Makhkamov Iqbol, Assistant Ferghana Polytechnicl Institute, Fergana, Uzbekistan.

(C) The Authors. Published by Blue Eyes Intelligence Engineering and Sciences Publication (BEIESP). This is an open access article under the CC BY-NC-ND license (http://creativecommons.org/licenses/by-nc-nd/4.0/) process of drying, purifying and refining, as well as improving the dust and air purification systems. should be increased.

All atmospheric air is divided into two types of process and aspiration: the first comes from the process equipment and the other from the exhaust systems.

In the technological processes of the ginneries, air transport is transmitted to the garment drying and cleaning shop. Depending on the location of the workshops at the ginneries, it will have two or three reloading points, which are independent sources of dust. The highest pollution in these points is $1200-1500 \mathrm{mg} / \mathrm{m}^{3}$. High-humidity low-grade cotton can be subjected to a large amount of dust leakage after drying. The dust emanating from the cotton pneumatic system is predominant with fine dispersion particles, mainly loose particles [1].

Most of the dust from the process of ginneries comes from pneumatic vehicles in the transportation of cotton and fiber.

\section{LITERATURE REVIEW}

The first air carrier was used in 1893 by Dorfman [2] to unload grain from ships. The device's operating efficiency is small and consumes a lot of energy. Nevertheless, it has been widely used in Europe for grain production. This is because airborne machines have a number of advantages over mechanical carriers. Pneumatic transport has also been successfully used in grain processing, chemistry, and construction [3]. The development of science and technology has expanded the scope of pneumatic transport equipment. In particular, the emergence of new ways of transporting material in boxes and pneumatic transport [4] opened new prospects for this area.In the cotton industry, pneumatic transport has been used since 1929. The first research of cotton pneumatic transport was carried out by Boris Levkovich. Later on, Bayduk made a major contribution to his development. He is the author of experimental studies on the interaction of cotton with air in pneumatic equipment, air and material resistance of pneumatic transport, material movement along horizontal and vertical pipes, radius of pneumatic transport, energy consumption in air transport [5]. Advances in scientific research so far have helped to improve the air transportation process, and, thanks to the use of many technical solutions created by scientists, the technical and technological parameters of the Cotton Vehicles have significantly improved. However, the

development of science requires constant improvement of technology and technology.

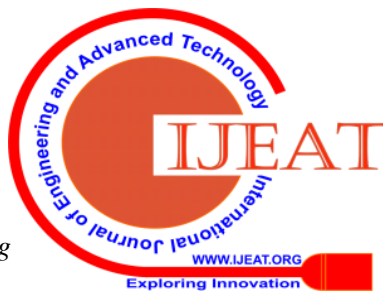




\section{RESEARCH METHODS}

Therefore, it is necessary to know the amount of air absorbed from each of the machines and equipment of the technological process (Table 1). The dust from the ginneries' machinery disperses the air into the environment and pollutes it. The dust from the dry-cleaning shop is less than 5-7 $\mathrm{mg} / \mathrm{m} 3$ of dust in the indoor air where only drying machines are located. This is due to the high moisture content of the cotton into the dryers, which prevents the separation of fine dust from the mass. Large disperse dust, even in high humidity, decomposes and fails to disperse in the building.

Table 1The Volume Of Air Absorbed From The Main Process Equipment Of Ginneries

\begin{tabular}{|c|c|c|c|}
\hline Equipments & $\begin{array}{c}\text { Equipment } \\
\text { suction location. }\end{array}$ & $\begin{array}{c}\text { The volume of } \\
\text { absorbed air } \\
\left(\mathrm{m}^{3} / \mathrm{s}\right)\end{array}$ & $\begin{array}{l}\text { Output tube } \\
\text { diameter, mm }\end{array}$ \\
\hline Cleaners ChX-5 & $\begin{array}{l}\text { The rear wall of } \\
\text { the equipment }\end{array}$ & 0,4 & 160 \\
\hline $\begin{array}{l}\text { OBM-A fiber waste } \\
\text { cleaner }\end{array}$ & $\begin{array}{l}\text { Dirty with dirty } \\
\text { unloading the } \\
\text { screwdriver } \\
\text { from the hole }\end{array}$ & 0,25 & 140 \\
\hline Gin & & & \\
\hline 4DP-130 & From the supplier & $0,2-0,25$ & 125 \\
\hline \multirow[t]{3}{*}{ Roll DV1M } & From the supplier & 0,2 & 125 \\
\hline & $\begin{array}{c}\text { From } 6 \text { screws to } \\
\text { linters }\end{array}$ & 1,4 & 285 \\
\hline & $\begin{array}{c}\text { From } 6 \text { screws to } \\
\text { linters }\end{array}$ & 1,8 & 355 \\
\hline \multicolumn{4}{|l|}{ Elevator } \\
\hline For cotton & $\begin{array}{c}\text { From the lower } \\
\text { thigh of the } \\
\text { elevator }\end{array}$ & 0,2 & 130 \\
\hline For seeds & $\begin{array}{l}\text { from the bottom } \\
\text { leading drum } \\
\text { surface }\end{array}$ & 0,2 & 130 \\
\hline For waste & 150 mm away & 0,25 & 130 \\
\hline
\end{tabular}

Drying compartments cause dustiness in the drying compartments with an air drying agent. This dust, even with a rough dispersion, sits in the dryer along with the gas flow to the roof of the building and the ground near the drying shop. The amount of dust emitted is 500-600 kg per day [7].

The current of the existing drying dews mines the speed of the drying agent moving from 1.3 to $2.5 \mathrm{~m} / \mathrm{s}$ (depending on the performance of the drying drum and the humidity of the cotton drum). This velocity is higher than the rotation rate of some cotton fibers and dirty impurities and ensures that particles of up to $5 \mathrm{~mm}$ in width are penetrated to the roof.

The dust in the compartment is the air that is emitted from the cotton pneumatic system, which is an indispensable dust in the dry-cleaning shop, as well as the dust generated by cleaning machines. It is powdery, with less fractional mineral fractions. The small fractions consist mainly of crushed dirty particles.
Powdered air is also isolated from aspirate systems of gin suppliers, which absorb absorbed air or polluted air from pollutants. This absorption system can be included in the aspiration of the cotton distribution screw.

Technical seeds from the lintering zone are transmitted to temporary storage facilities with tape or screwdriver. They contain dust in the form of short fibers and cotton seeds. Low-grade seeds have more dust than the first type. This is explained by the fact that the low cotton seeds and shell are not very durable and are easily damaged by the working bodies of technological machines. Exactly refers to cotton seeds with high moisture content, which are heated and then rapidly dried. Thus, the proper storage of cotton at the cotton processing points prior to its processing at the ginneries determines the sanitary conditions of production. The main properties of the dust on the seeds are similar to that of the lint air in the liner shop.

At the cotton mill, the dust content of the process changes during the process. At the beginning of the initial cotton processing, dust is released from the air, which contains large amounts of mineral fractions. In subsequent cotton processing - fiber and fibers are more concentrated in the dust, such as cotton seeds, leaf slices and other parts of cotton, as well as fibers. At the end of the technological process, for example: lintering, pressing units, separation of seeds and complete dehydration shop, the dust that is released into the air will usually contain fibrous particles mixed with the seeds.

Cotton mixes vary in composition and size. Waste, dirty and dusty process is carried out in all technological processes of cotton processing - starting with air transport and finishing with the main case. Waste containing up to $14 \%$ of fiber material is considered to be irreplaceable waste and is not used.

Cotton, fiber, lint and industrial waste are the main air exits in the ginneries.

In order to identify problems that can make it difficult for cotton gin dusting, it is necessary to determine the fiber content of the powders in each process.

\section{RESULTS AND DISCUSSION}

As far as we know, dirty mixing machines consisting of mineral and organic fractions that have been extracted from cotton in the Waste Waste Machines also contain immature seeds (dead) and immature single seeds.

At the ginneries cotton fiber is continuously collected and processed by air transport to the processing area of a particular lot. Fiber wastes are processed for a particular type of fiber waste in a specialized plant for processing fiber waste according to the most advanced technology.

Purified fiber wastes are penetrated into penco-jute bags by types, types, varieties and groups using a screwdriver inserted into the design of the fibers.

Fiber waste cases are stored in the recycling department until pressed. Fiber 'waste is collected by hydraulic presses of a separate linearization unit with a mass of about $220 \mathrm{~kg}$ of waste of one type, type, grade or group according to the concentration. 
Research conducted by the Republican Scientific Center for Cotton Industry allowed to determine the optimal amount of dust to be removed from the process equipment. In the course of the cotton harvesting process, a large amount of waste is emitted in all technological processes, either waste or secondary raw materials (fiber waste) or irreversible waste. It is found that only one cotton gin industry produces 150-350 tonnes of waste per year by industry type, irreversible emissions amount to 5 - 6 tonnes, and $70-90 \%$ of non-organic waste. It serves as a feedstock for the use of animal waste in feeds for agriculture [8].

Researches have been carried out at the Karasuv, Tashkent, Mustaqillik and Ginnery factories in the Tashkent region and the Metan cotton ginneries located in the Republic of Uzbekistan (Figure 1) to determine the amount of emissions from the ginneries (Figure 1).

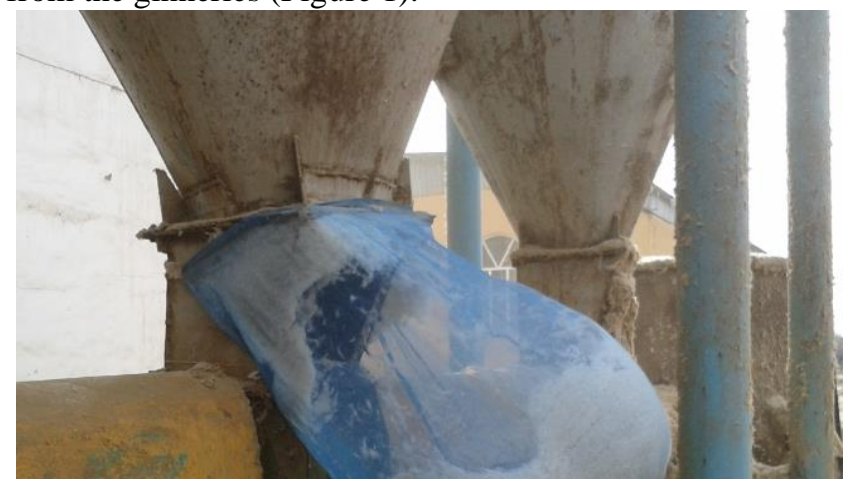

Figure 1. Deterrence of fiber waste from VZP-type dust collector at the Metan Cotton Ginning Plant in Samarkand Region

According to the results of research. For each technological process of the ginneries, the amount of fiber discharged by pneumatic transport is kept on a $1 \mathrm{x} 1 \mathrm{~mm}$ grid (Figure 2).

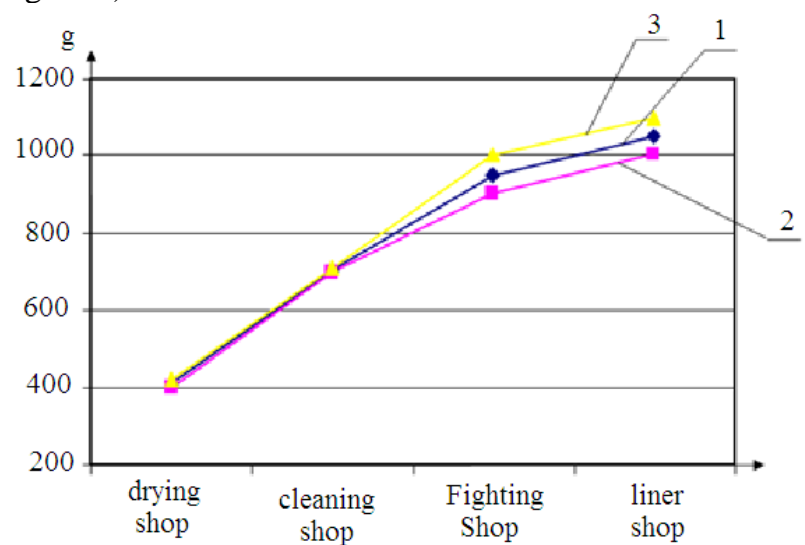

Figure 2. The amount of fiber waste that comes out of the ginneries within $\mathbf{3 0}$ minutes

1. Methane; 2. Karasuv; 3. Plants of Mustaqillik. drying shop

It turns out that at the beginning of the process of cotton ginneries, the amount of fiber waste in the drying shop is $400 \mathrm{~g}$. Fiber emissions from the assembly and fitting shops range from 900 to $1200 \mathrm{~g}$, which in addition to economic damage also causes damage to the atmosphere [6].

Scientific studies on the determination of fibrous emissions from dust traps into the atmosphere are when the dusting hole of the dust retainer is closed by a grid $1 \mathrm{x} 1 \mathrm{~mm}$ (Figure 3).

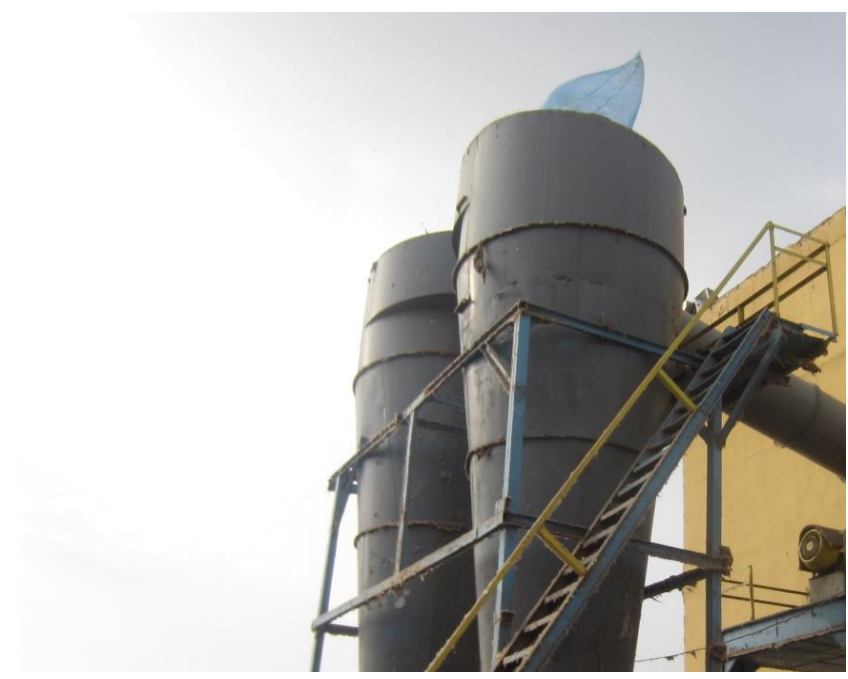

Figure 3. Deterrence of fibrous waste from the Karasuv ginnery

Fiber emissions from the dust trap into the atmosphere are captured by each of our companies and analyzed in Figure 4

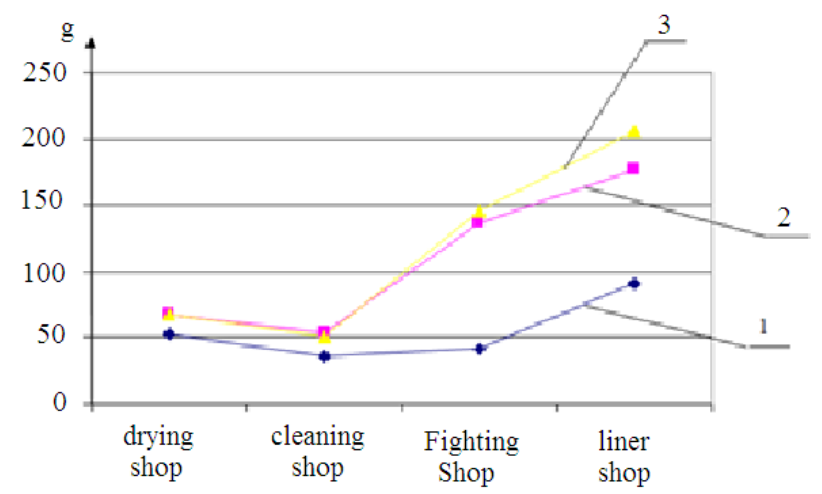

Figure 4. Fiber emissions from dust traps into the atmosphere within $\mathbf{3 0}$ minutes

1. Methane; 2. Karasuv; 3. Plants of Mustaqillik.

As can be seen from the graph, the initial stage of the technological process is the amount of fibrous waste emitted within 30 minutes from the drying shop, $400 \mathrm{~g}$, from the cleaning shop this figure is $600 \mathrm{~g}$, in the welding shop $900 \mathrm{~g}$ and in the liner shop $1000 \mathrm{~g}$. This shows that the amount of fibrous emissions in the Karasu, Mustaqillik and Metan ginneries is higher than the emissions within 30 minutes. By keeping these fibrous waste, first, reducing the damage to workers and surrounding communities, and secondly, we will have the opportunity to re-use waste emissions, and thirdly, the efficiency of the dust collectors used at the enterprise will increase [9].

The dust captures of the dust holders and the air and exhaust holes were placed on a $1 \mathrm{x} 1$ grid and held for 0.5 hours in the fibrous, mineral and organic dust contents of the dusty air. The results of the experiments are presented in Table 2.

The effect of the grass surface on the speed of air passing through the fibrous waste disposal device is shown in (Figure $3)$. 
Table 2. The amount of fiber waste from a ginnery

\begin{tabular}{|c|c|c|c|}
\hline $\begin{array}{l}\text { Technological } \\
\text { processes }\end{array}$ & 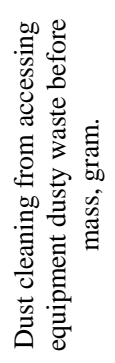 & 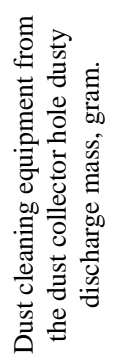 & 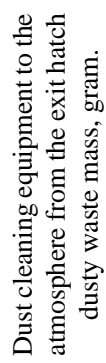 \\
\hline $\begin{array}{l}\text { 2SB-10 drying } \\
\text { drum }\end{array}$ & 400 & 300 & 100 \\
\hline $\begin{array}{c}\text { Cleaning of UXK } \\
\text { flow }\end{array}$ & 700 & 550 & 150 \\
\hline $\begin{array}{l}\text { 4DP-130 Gin } \\
\text { equipments }\end{array}$ & 900 & 700 & 200 \\
\hline $\begin{array}{l}\text { 5LP Linter } \\
\text { equipment }\end{array}$ & 1000 & 750 & 250 \\
\hline
\end{tabular}

\section{CONCLUSIONS}

Analysis shows that up to $20-30 \%$ of the dust particles in the air are absorbed into the air, causing pollution to the atmosphere. So, we need to take measures to collect fiber. Currently, cotton ginneries are continuously collecting fibers from the bottom of the dust collectors through sacks during the cotton processing of a particular installment.

Fiber wastes are collected by hydraulic presses of a separate linearization unit with a mass of about $220 \mathrm{~kg}$ of waste of one type, type, grade or group. This requires hard work.

From the results we can see that the waste from the ginneries is high in fiber content. If this equipment is developed, it may also increase the efficiency of cleaning dust collectors. In addition, technological waste can be retained and reused as a waste.

\section{REFERENCES}

1. Khodjiev M., Abbazov I., Alimov O., Karimova R. The Composition of Releasing Passion of Dusty in the Process of Pat // International Journal of Engineering and Advanced Technology (IJEAT) ISSN: 2249-8958. Volume-8, Issue-3S, February 2019. 279-283

2. Galitsky R.R. Equipment for grain processing enterprises. Moscow., Kolos, 1982, 288 pp.

3. V. Kuznetsov, S. Denisov. Pneumotransport of woodworking enterprises. Bratsk State Technical University. Bratsk., 2007.

4. K. Hoganson, D. Gross. PatentUSA. Variable speed drive for pneumatic transport system. US 7,950,879 B2. 05/31/2011.

5. Baydyuk P.V., Khozhiev M.Kh. Methodology for determining hydraulic pressure losses in a horizontal working pipeline of a pneumatic conveying system for raw cotton. // R.Zh. Cotton industry. 1992. No. 2.C. 8-9.

6. Khodjiev M., Abbazov I., Karimov J. A New Technology for Dust Removal From Cotton Processing // International Journal of Recent Technology and Engineering (IJRTE) ISSN: 2277-3878, Volume-8 Issue-3, September 2019, DOI:10.35940/ijrte.B2073.098319 -pp 583-586

7. Abbazov, I., Sarimsakov, O., Khodjiev, M. and Mardonov, B. (2018) Waste Produced at Cotton Waste Factories. American Journal of ASCIT Communications, 5,22-28.

8. Abbazov I.Z., Khodjiev M.T., Karshyev B.E. Increase of an overall performance of a deduster on cotton ginning enterprises // European Science Review. DOI:http://dx.doi.org/10.20534/ESR-16-9.10-171-177

9. Khodjiev M., Abbazov I., Alimov O., Karimov J. Fraction Structure of Cotton Cleaning Equipment in Cotton Enterprises and Their Cleaning
Effectiveness // International Journal of Advanced Research in Science, Engineering and Technology ISSN: 2350-0328. Vol. 6, Issue 1, January 2019. 7983-7988

10. Xojiyev MT;Abbazov, IZ;va Alimov, O.H; (2019) "Paxta tozalash zavodlarida ishlab chiqarilgan" Paxta tolasini toza tozalashning yo'llari, O'zbekiston To'qimachilik jurnali: Vol.1: № 1, 2-modda. Eliktronmanzili: https://uzjournals.edu.uz/titli/vol1/iss1/2

\section{AUTHORS PROFILE}

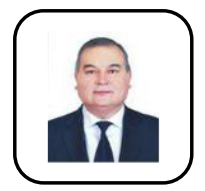

Xodjiev Muksin Tadjievich was born on November 29, 1957 in Kokand, Ferghana region, in the educated family. In 1975 he entered the Tashkent Institute of Textile and Light Industry. He began his career at the Scientific Laboratory of Cotton Initial Processing from 1980. In 1989, he began his career in the Technology of Textile Materials and Pre-Raw Materials Processing Specialist Candidate of technical sciences.1998 PhD in technical sciences on textile materials technology and initial processing of raw materials was. Today Rector of Gulistan State University. e-mail: m.xojiyev@titli.uz, phone: +99890-4005779

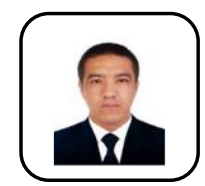

Abbazov Ilhom Zapirovich was born in 1986 in Ishtikhan district of Samarkand region. He was accepted to the 1st class in the school No. 33 in Ishtihon district. In 2000 she was admitted to the lyceum №1 directed to the exact subjects. In 2005 he entered the Tashkent Institute of Textile and Light Industry on the basis of state grant. Since 2011, she worked at the Tashkent Institute of Textile and Light Industry and the department of Ecology. PhD in Technical Science and Technology of Raw Material Processing (Ph.D). Today docent of Jizzakh Polytechnical Institute e-mail: i.abbazov@titli.uz, phone: +99899-8114986

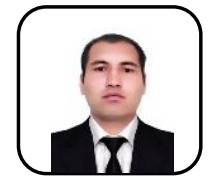

Ikbal Makhkamov was born in 1993 in the Fergana region of Uzbekistan. In 2013 he entered the Tashkent Institute of textile and light industry on a contract basis. In 2017, she entered the master's program of the Tashkent Institute of textile and light industry on the basis of a state grant. In 2019 he graduated from Tashkent Institute of textile and light industry with a master's degree. Currently he is an assistant of the Department "Technology and equipment of light industry" of Fergana Polytechnic Institute. e-mail: gulomzopirov@gmail.com, phone: +99890-3092623 